\title{
Pelatihan Peningkatan Kompetensi Pembuatan Video Iklan Bagi UMKM Kelurahan Gebangsari Kecamatan Genuk Semarang
}

\author{
Firdaus Azwar Ersyad', Fajriannoor Fanani² $^{2}$ Suhariyanto $^{3}$ \\ 1,2,3 Universitas Semarang \\ Jl. Soekarno Hatta, Tlogosari Kulon, Kec. Pedurungan, Kota Semarang, Indonesia \\ e-mail: ${ }^{1}$ firdaus.azwar@usm.ac.id, ${ }^{2}$ fajrian@usm.ac.id, ${ }^{3}$ suhariyanto@usm.ac.id
}

\begin{abstract}
Abstrak
Kegiatan pengabdian ini bertujuan untuk meningkatkan komptensi pelaku UMKM di Kelurahan Gebangsari, Semarang. Era perkembangan teknologi digital yang terus maju tak terbendung ini, aktivitas mempromosikan brand atau melakukan marketing campaign dapat dilakukan dengan berbagai macam cara dan kreativitas sesuai kadar kebutuhan dan kemampuan mereka. Terlebih disaat ini di berbagai media massa bebas tanpa batas sebagai media periklanan, salah satunya adalah media social/Cyber seperti WhatsApp, Facebook, Email, Youtube dan masih banyak aplikasi lain, semua ini sebagai sarana promosi dengan berbagai konten sebagai ajang iklan geratis guna meningkatkan penjualan produk mereka. Dengan demikian, tantangan pemasar saat ini adalah menentukan bentuk konten yang paling efektif berdasarkan sasaran konsumen. Dan salah satu bentuk konten yang kini sedang digemari adalah video iklan singkat dengan komunikasi sederhana dan tak sedikit pula video iklan di media Cyber viral karena sentuhan kreatifitas. UMKM Kelurahan Gebangsari, Kecamatan Genuk Semarang merupakan salah satu wilayah dengan jumlah pelaku usaha yang cukup banyak di kota Semarang. Untuk meningkatkan penjualan maka pelaku usaha membutuhkan strategi pemasaran yang efektif melalui media massa Cyber untuk dapat meningkatkan target penjualan produk mereka.
\end{abstract}

Kata Kunci : Komunikasi Efektif, Video Iklan, UMKM Kelurahan Gebangsari.

\begin{abstract}
This program aims to improve the ability of UMKM players in Gebangsari Village, Semarang. The era of digital technology development that continues to advance is unstoppable, activities to promote brands or conduct marketing campaigns can be carried out in various ways and creativity according to the level of their needs and abilities. Especially at this time in various free mass media without limits as an advertising medium, one of which is social / cyber media such as WhatsApp, Facebook, Email, Youtube and many other applications, all of this as a means of promotion with various content as a free advertising platform to increase sales. their product. Thus, the challenge for marketers today is to determine the most effective form of content based on target consumers. And one form of content that is currently in vogue is short video advertisements with simple communication and not a few video advertisements in Cyber media are viral because of a touch of creativity. UMKM Gebangsari Village, Genuk District, Semarang is one of the areas with quite a lot of business actors in the city of Semarang. To increase sales, business actors need an effective marketing strategy through cyber mass media to be able to increase their product sales targets.
\end{abstract}

Keywords: Effective Communication, Video Advertising, Gebangsari UMKM. 


\section{Pendahuluan}

Berdasarkan data dari Dinas Koperasi, Usaha Mikro Kecil dan Menengah (UMKM) Kota Semarang mencatat bahwa ada 17.526 pelaku UMKM yang sudah berizin. Angka tersebut baru sekitar 20 persen yang sudah menggunakan teknologi dalam pemasarannya. Kepala Dinas Koperasi dan UMKM Kota Semarang FX Bambang Suranggono, mengatakan, saat ini pemerintah terus mendorong pelaku UMKM supaya mulai beralih dengan memanfaatkan teknologi Pelaku UMKM diminta tak hanya aktif berbisnis dengan sistem konvensional (Fitria, 2020). Dari data tersebut terlihat bahwa saat ini pelaku UMKM khususnya di kota Semarang harus lebih adaptif dalam menghadapi era teknologi digital guna dapat menunjang usahanya. Proses promosi UMKM memang pada dasarnya dapat digunakan dengan berbagai cara baik dengan cara konvensional dan dengan cara digital. Namun seiring dengan kemajuan zaman khususnya pada bidang promosi, saat ini media promosi telah beralih ke media digital, salah satunya dalam bentuk video. Video promosi memiliki beberapa kelebihan dibanding media promosi konvensional lainnya, yakni memiliki daya jangkau yang luas, menampilkan realita objek, dan dapat diaplikasikan di berbagai macam media digital, seperti televisi, Youtube, website travel, media sosial, dan sebagainya. Dalam penerapannya, video promosi sering di gunakan sebagai media untuk memperkenalkan atau mengingatkan kembali informasi mengenai suatu produk, jasa, acara, maupun sebuah destinasi.

Di era digital ini, video promosi atau video marketing bisa menjadi solusi bagi UMKM untuk dapat menjangkau para konsumennya. Selain biaya yang dikeluarkan dapat lebih efektif. Berdasarkan data Marketingcharts.com, 57\% konsumen akan menonton setidaknya 2 menit video mengenai edukasi produk yang akan mereka beli. Tidak hanya itu, video juga memiliki kemampuan untuk mengajak para penontonnya untuk tertawa, menangis, belajar dan mengambil keputusan. Dengan demikian ketrampilan ini layak untuk didalami bagi UMKM guna dapat memberi impak kepada penjualan.

UMKM Kelurahan Gebangsari, Kecamatan Genuk Semarang merupakan salah satu wilayah dengan jumlah pelaku usaha yang cukup banyak di kota Semarang. Untuk meningkatkan penjualan maka pelaku usaha membutuhkan strategi pemasaran yang efektif melalui media massa atau Cyber untuk dapat meningkatkan target penjualan produk mereka. Dengan demikian, rancangan pengabdian ini berupaya meningkatkan kompetensi para pelaku usaha dalam pembuatan video iklan singkat. Hal tersebut senada dengan apa yang dikemukakan oleh Natalia Sari Pujiastuti selaku faounder tangan terampil bahwa saat ini para pelaku UMKM belum memiliki ketrampilan dalam pembutan konten promosi. Dengan demikian, para pelaku UMKM wajib belajar sebagai upaya mendukung kegiatan usaha mereka. Permasalahan yang dihadapi saat ini yakni kurangnya kemampuan pembuatan video iklan singkat sebagai video marketing Pelaku UMKM kelurahan Gebangsari Kecamatan Genuk Kota Semarang guna sebagai upaya pengambangan ketrampilan dalam Pembuatan video marketing. Kondisi tersebut membutuhkan penanganan barupa pengabdian yang akan memberikan pelatihan mengenai pembuatan video iklan singkat dengan komunikasi efektif sebagai video marketing. 


\section{Metode}

Pengabdian dilakukan di Kampus Universitas Semarang. Selama satu hari. Tim pengabdian membuat dua metode, yakni :

a. Metode Teoritis yang dituangkan dalam modul pengabdian yang berisi tentang 'Materi peningkatan kompetensi pembuatan video iklan singkat dengan komunikasi efektif bagi pelaku UMKM kelurahan Gebangsari Kecamatan Genuk Kota Semarang'.

b. Metode Praktek yang dilakukan dengan praktek pembuatan video iklan dalam bentuk praktek, diskusi, hingga dilanjutkan tanya jawab antara mentor dengan pelaku UMKM kelurahan Gebangsari Kecamatan Genuk Kota Semarang, dengan alokasi waktu pengabdian berlangsung selama empat jam (08:30 - 12:30).

Metode yang digunakan yakni di awali dengan perkenalan dari masing-masing pembicara, diikuti dengan:

1. Diskusi untuk melihat sejauh mana keluhan dan pemahaman peserta dalam melakukan promosi produk lewat media sosial yang selama ini mereka lakukan.

2. Penyampaian Materi yang terdiri :

a. Komunikasi Efektif oleh Fajriannoor Fanani, M.I.Kom

b. Strategi pembuatan iklan di media massa oleh Suhariyanto, S.Sos.I., M.I.Kom

c. Pembuatan Video dan Strategi Branding Video Iklan di media sosial/ Cyber oleh Firdaus Azwar Ersyad, S.Sn., M.Sn

Tahap terakhir pelaku UMKM kelurahan Gebangsari Kecamatan Genuk Kota Semarang diminta untuk mengisi post test untuk mengukur sejauh mana pemahaman tentang pembuatan da pentingnya video iklan sebagai sarana video marketing di media sosial demi menigkatkan penjualan produk mereka. Adapun kuesioner evaluasi dalam pelatihan ini adalah sebagai berikut :

a. Apakah yang dimaksud komunikasi efektif?

b. Bagaimana cara pembuatan video iklan singkat yang efektif?

c. Bagaimana cara dan strategi pengiklanan produk lewat media sosial?

Disamping mengukur keberhasilan melalui kuesioner, tolok ukur yang juga menunjukkan keberhasilan dari pelatihan ini tentunya adalah kemampuan dan keberanian dalam menuangkan ide kreatif mereka baik dalam pembuatan video iklan singkat sebagai sarana iklan marketing di media sosial dan cara share di media sosial itu sendiri sebagai usaha pengenalan produk mereka.

\section{Hasil dan Pembahasan}

Pelatihan dalam pembuatan video marketing dilakukan oleh Tim pengabdian guna memberikan pengetahuan dan pengalaman, dengan mengajarkan secara langsung terkait. pembuatan video iklan singkat dengan komunikasi efektif sebagai video marketing bagi pelaku UMKM kelurahan Gebangsari Kecamatan Genuk Kota Semarang. Kegiatan ini berlangsung dalam satu hari dilakukan di kampus universitas Semarang. 


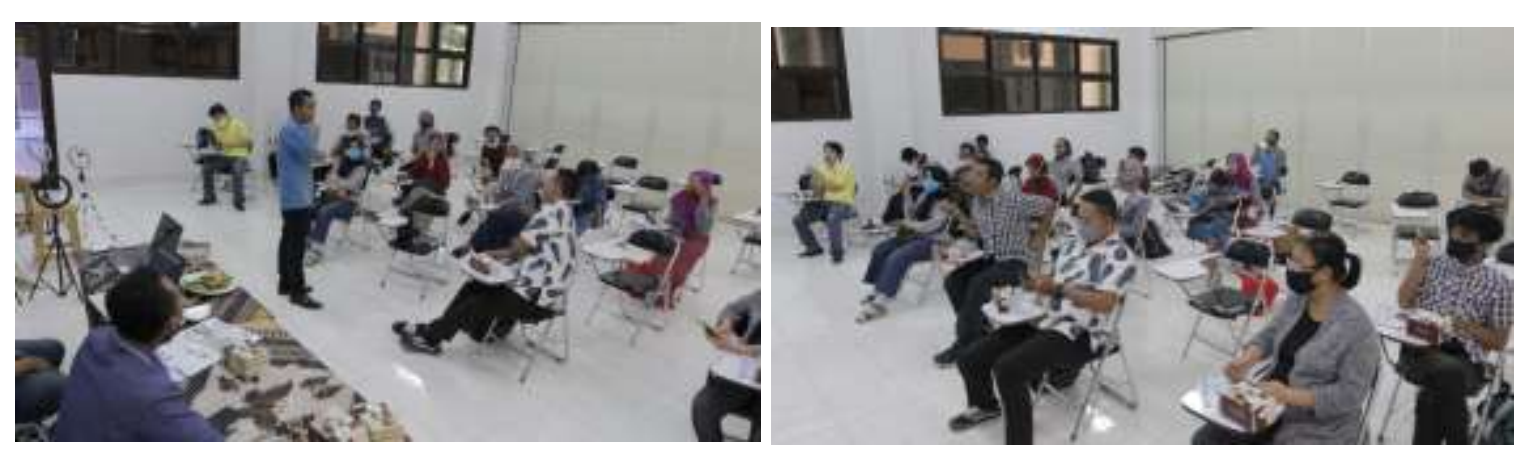

Gambar 1. Kegiatan Pelatihan Pembuatan Video Marketing

Kegiatan pengabdian kepada pelaku UMKM kelurahan Gebangsari Kecamatan Genuk Kota Semarang dilakukan dengan persiapan melakukan koordinasi dengan Kepala UMKM kelurahan Gebangsari Kecamatan Genuk Kota Semarang. Terkait waktu dan tempat pelaksanaan. Selanjutnya mengajukan surat ijin dan proposal kegiatan UMKM kelurahan Gebangsari Kecamatan Genuk Kota Semarang. Tim pengabdian menyusun materi yang dipaparkan pada saat pengabdian berlangsung. Dalam kegiatan ini terdapat tiga pemapar materi yang masing-masing menjelaskan materinya. Pengabdian dilaksanakan di kelurahan Gebangsari Kecamatan Genuk Kota Semarang/ Online dari USM. Fajriannoor Fanani, M.I.Kom menjelaskan tentang Komunikasi Efektif, Suhariyanto, S.Sos.I., M.I.Kom menjelaskan Strategi pembuatan iklan di media massa, sedangkan Firdaus Azwar Ersyad, M.Sn. menjelaskan mengenai Pembuatan Video dan Strategi Branding Video Iklan di media sosial/ Cyber.

Adapun Hasil yang dapat diperoleh dari kegiatan pengabdian ini adalah sebagai berikut:

a. Para pelaku UMKM Kelurahan Gebangsari lebih mengerti dan paham tentang pentingnya video marketing dalam dunia pemasaran untuk kepentingan penyebarluasan informasi terkait produk yang dijual.

b. Para pelaku UMKM Kelurahan Gebangsari mendapat pengalaman bagaimana membuat konsep video, mengolah mengedit video dan gambar melalui aplikasi Android.

Hasil pengabdian menunjukkan bahwa peserta cukup antusisas dalam mengikuti rangkaian workshop. Antusiasme peserta terlihat mulai dari sesi materi yang mendapatkan perhatian penuh oleh para peserta, juga pada sesi praktek yang memperlihatkan ketertarikan peserta pada pelaksanaan praktek. Bahkan peserta tampak seolah-olah berlomba agar tim prakteknya mendapatkan hasil yang terbaik. Peserta juga tampak antusisas dari pertanyaan yang diajukan selama workshop berlangsung. Adapun manfaat yang diperoleh dari hasil yang telah dicapai dalam workshop ini sebagai berikut:

a. Menambah pengetahuan peserta tentang pentingnya ilmu marketing khususnya dalam pemanfaatan video sebagai promosi produk yang mereka jual. Peserta juga mendapat pengetahuan dalam terkait prosedur yang benar dalam menyajikan sebuah video dengan elemen komunikasi guna mengoptimalkan daya promosi melalui video marketing

b. Menambah pengetahuan peserta tentang bagaimana merancang dan menghasilkan gambar/video yang menarik untuk kebutuhan promosi dalam rangka penyebaran promosi audio visual guna meningkatkan omset para pelaku UMKM. 
Evaluasi keberhasilan kegiatan pengabdian ini dilakukan setelah kegiatan selesai. Indikator keberhasilan dari kegiatan pengabdian ini dilihat dari faktor berikut: Respon positif dari para peserta yang dilihat dari pemahaman peserta dalam mengerjakan soal essay yang benar dan lebih tepat serta didukung dengan hasil karya dari para peserta. Tahapan pelaksanaan pengabdian yang sudah dilakukan sampai saat ini adalah pada tahapan pelatihan peserta pelaku UMKM dalam pemanfaatan video marketing untuk mendongkrak penjualan. Hasil yang diharapkan pada tahap ini adalah peserta dapat mengimplementasikan cara pembuatan video marketing yang efektif. Adapun rencana pada tahapan selanjutnya adalah pendampingan pelaku UMKM dapat memanfaatkan social media sebagai media promosi dengan didukung konten video marketing yang menarik. Kegiatan pengabdian masyarakat yang dilakukan di UMKM Gerbangsari ini juga mempunyai luaran berupa Publikasi pada media masa (cetak/elektronik) yang saat ini sudah terbit publish pada: https://www.suaramerdeka.com/regional/semarang/247227-pelaku-umkm-kecamatan-genukdilatih-buat-video-promosi-produk

\section{Kesimpulan}

Dengan adanya kegiatan pengabdian ini para para pelaku UMKM kelurahan gebangsari Semarang dapat lebih memahami apa yang dimaksud dengan Video Marketing secara komprehensif. Di kemudian hari para peserta dapat meningkatkan ketrampilan video marketing yang terkait dengan kebutuhan dalam memperkenalkan produk hingga membuat konten kreatif guna memperkenalkan produk unggulanya yang dapat di publikasi di website dan media social. Adapun saran bagi peserta agar dapat terus mengasah kemampuannya untuk mengelaborasi materi yang sudah didapat melalui pelatihan. Dan diharapkan pula ketrampilan yang didapat juga bisa diteruskan ke para pelaku UMKM lain, sehingga ketrampilan video marketing tidak hanya dikuasai oleh beberapa orang saja melainkan dapat di miliki oleh beberapa pelaku UMKM yang belum mendapatkan wawasan atau ketrampilan dalam pembuatan video marketing.

\section{Penghargaan}

Penulis mengucapkan terima kasih atas dukungan dan partisipasi dari berbagai pihak sampai terselesainya kegiatan ini. Adapun pihak LPPM Universitas Semarang yang telah mendukung penuh kegiatan ini. Serta para peserta, pelaku UMKM Kelurahan Gebangsari, atas atusiasnya dan dapat berpartisipasi aktif dalam kegiatan pelatihan.

\section{Daftar Pustaka}

A.M, Morissan. (2010). Periklanan komunikasi pemasaran terpadu, Penerbit.

Kencana. Jakarta.

Asep Syamsul M. Romli, Broadcast journalism (Panduan Menjadi Penyiar, Reporter dan Script Writer)

Agus Tiarso.(2005). Penulisan naskah multimedia. (Bahan sajian pelatihan). Semarang : BPM Fiske, John. (2012). Pengantar Ilmu Komunikasi. Jakarta: Rajagrafindo Persada

Joseph V Mascelli, ASC. (1986). Close up, angle, komposisi, kontiniti, editing dalam sinematografi. Terjemahan HMY. Biran. Jakarta : Yayasan Citra

Mulyana, Deddy. (2010). Ilmu Komunikasi Suatau Pengantar. Bandung: Remaja Rosdakarya. 